\title{
REVIEW
}

\section{Supracricoid laryngectomy for recurrent laryngeal cancer after chemoradiotherapy: a systematic review and meta-analysis}

\author{
Laringectomia sopracricoidea per il trattamento del cancro laringeo dopo recidiva \\ di radioterapia: revisione sistematica della letteratura e metanalisi
}

\author{
C.A. LEONE, P. CAPASSO, D. TOPAZIO, G. RUSSO \\ Otolaryngology Head and Neck Surgery Unit of "Azienda Ospedaliera di Rilievo Nazionale dei Colli, Ospedale \\ Monaldi", Naples, Italy
}

\section{SUMMARY}

Residual or recurrent laryngeal cancer after irradiation is a difficult clinical problem with a rate that ranges from $13 \%$ to $36 \%$ of cases. Supracricoid laryngectomy (SCL) with cricohyoidopexy (CHP) or cricohyoidoepiglottopexy (CHEP) provide reliable oncological and functional results for selected primary and recurrent patients with glottic and supraglottic carcinomas. We conducted a systematic review and meta-analysis to assess the oncological and functional outcomes of patients treated with open partial horizontal laryngectomy types IIa and IIb (CHEP, CHP) in terms of the recurrence of squamocellular cancer of the larynx after radiotherapy failure. The databases searched included MEDLINE, PubMed and EMBASE (from January 1990 to December 2015, English language). The meta-analysis was performed with a mixed random effects model using the DerSimonian and Laird method. The heterogeneity was measured with the $\mathrm{I}^{2}$ statistic. Fourteen papers out of 276 were included and comprised a total of 291 patients. The five-year overall survival was 80.2\% (CI $0.719-0.885$; $\mathrm{I}^{2}=62 \% ; \mathrm{p}=0.003$ ), and the 5-year disease-free survival was $89.5 \%\left(\mathrm{CI} 0.838-0.952 ; \mathrm{I}^{2}=52 \% ; \mathrm{p}=0.022\right)$. The indications for SCL after the failure of radiation therapy (RT) were similar to those specified for previously untreated patients. We therefore hypothesised that careful assessment of tumour extension might be responsible for the high 5-year OS and 5-year DFS. The early postoperative recovery outcomes indicated that the mean time until decannulation was 35.6 days (CI 24.3-46.9; $\mathrm{I}^{2}=95 \% ; \mathrm{p}<0.001$ ), and the mean time until nasogastric tube (NGT) or percutaneous endoscopic gastrostomy (PEG) removal was 28.3 days (CI 22.7-33.8; $\mathrm{I}^{2}=86 \%$; $<<=0.001$ ). These data are according to authors who prefer the initial removal of the NGT and the initiation of oral alimentation with a tracheostomy tube to protect and clean the airways and permit the suction of any residual food that might be present.

KEY WORDS: Laryngeal cancer $\bullet$ Recurrence $\bullet$ Radiotherapy $\bullet$ Supracricoid laryngectomy $\bullet$ Meta-analysis

\section{RIASSUNTO}

La recidiva e la persistenza del cancro della laringe dopo radioterapia rappresentano eventi insidiosi, $i$ cui tassi di incidenza variano dal $13 \%$ al 36\%. L'intervento di laringectomia sopracricoidea (LSC), con cricoioidopessia (CIP) o cricoioidoepiglottopessia (CIEP), è in grado di garantire risultati oncologici e funzionali affidabili per i pazienti selezionati affetti da carcinoma glottico o sopraglottico, sia in caso di neoplasia primitiva che di recidiva. La presente metanalisi ha lo scopo di valutare i parametri oncologici e funzionali nei pazienti trattati con LSC per recidiva di carcinoma squamocellulare della laringe dopo fallimento di radioterapia. La ricerca è stata effettuata sui databases MEDLINE, PubMed ed EMBASE (da gennaio 1990 a dicembre 2015, solo in lingua inglese). Per la metanalisi è stato impiegato il metodo DerSimonian e Laird con effetto "midex random"; l'eterogeneicità è stata misurata mediante I ${ }^{2}$. Sono stati inclusi nella ricerca 276 articoli, tra i quali ne sono stati selezionati 14 per la metanalisi, per un totale di 291 pazienti. L'analisi statistica ha mostrato una sopravvivenza globale (OS) a 5 anni del 80,2\% (IC 0,719-0,885; $\left.I^{2}=62 \% ; p=0,003\right)$ e una sopravvivenza libera da malattia (DFS) a 5 anni del 89,5\% (IC 0,838-0,952; $\left.I^{2}=52 \% ; p=0,022\right)$. Le indicazioni chirurgiche per una LSC dopo fallimento di radioterapia non cambiano rispetto a quelle adottate per pazienti con tumore primitivo. Pertanto, è stato ipotizzato che l'attenta valutazione dell'estensione del tumore, in caso di recidiva, potrebbe essere responsabile dell'alto tasso di OS e DFS a 5 anni. Per quanto riguarda i parametri di valutazione funzionale precoce postoperatoria, il tempo medio di decannulazione è stato di 35,6 giorni (IC 24,3-46,9; $I^{2}=95 \%$; $\left.p<0,001\right)$, mentre il tempo medio di rimozione del sondino naso-gastrico ( $S N G)$ o della gastrostrostomia percutanea endoscopica (PEG) è stato di 28,3 giorni (IC 22,7-33,8; $\left.I^{2}=86 \% ; p<=0.001\right)$. Questi dati sono in accordo con gli Autori che preferiscono la rimozione precoce del sondino nasogastrico. In tal modo si può riprendere l'alimentazione orale quando è ancora presente il tubo endotracheale a protezione delle vie aree $e$ permettere l'aspirazione degli eventuali residui alimentari.

PAROLE CHIAVE: Cancro della laringe $\bullet$ Recidiva $\bullet$ Radioterapia $\bullet$ Laringectomia sopracricoidea $\bullet$ Meta analisi 


\section{Introduction}

Residual or recurrent laryngeal cancer after irradiation is a difficult clinical problem with a rate that ranges from $13 \%$ to $36 \%{ }^{1-4}$. Although several treatment options exist for patients affected with laryngeal cancer at first presentation $^{56}$, the options for those with recurrent cancer are limited based on the initial treatment received ${ }^{7}$. Cancers that recur after radiation therapy (RT) often exhibit aggressive behaviour, arise in a field in which lymphatic drainage is unpredictable and are associated with poor control rates ${ }^{8}$. Total laryngectomy is a frequently recommended option even for early recurrent cancers after chemoradiotherapy, but this procedure substantially impairs the quality of life primarily due to the permanent tracheostoma and the loss of the voice ${ }^{9}$. Supracricoid laryngectomies (SCLs) were recently classified by the European Laryngological Society ${ }^{10}$ as Open Partial Horizontal Laryngectomies Type II, which include reconstructions either by cricohyoidoepiglottopexy (CHEP; renamed OPHL Type IIa) or cricohyoidopexy (CHP; renamed OPHL Type IIb). Both of these procedures provide reliable oncological and functional results for selected primary and recurrent patients with glottic and supraglottic carcinomas ${ }^{11-14}$. Several reports regarding the effectiveness of SCLs in terms of survival and functional results considering residual and recurrent cancer have been published.

The aim of this systematic review and meta-analysis was to evaluate the pooled oncological and short-term postoperative recovery outcomes of supracricoid laryngectomies with $\mathrm{CHEP}$ and $\mathrm{CHP}$ in the setting of recurrent laryngeal squamocellular cancer (SCC) after chemoradiotherapy.

\section{Materials and methods}

\section{Data sources and searches}

We aimed to identify all papers that assessed the oncological and functional outcomes of patients treated with supracricoid laryngectomy for recurrence of SCC of the larynx after RT failure. The databases searched included MEDLINE, PubMed and EMBASE (from January 1990 to December 2015). We applied English language and abstract availability restrictions. Our search included the following keywords: laryngeal cancer, supracricoid laryngectomies, subtotal laryngectomy, cricohyoidopexy, cricohyoidoepiglottopexy, and/or retrospective study, prospective and randomised clinical study.

\section{Selection of studies}

Publications were included if they included patients affected with recurrent laryngeal SCC after initial treatment with RT that was salvaged with supracricoid laryngectomy and reported the 5-year overall survival (OS), 5-year disease free survival (DFS) and short-term postoperative recovery outcomes.
We included only full published papers and excluded abstracts and reviews. Papers containing inadequately separable oncological or functional data, series that included patients treated with different procedures and those focusing on other topics or other surgical techniques were excluded.

\section{Outcome measures}

The primary outcome was 5-year overall survival (OS). The secondary outcomes were 5-year disease-free survival (DFS), short-term postoperative recovery outcomes and 5-year OS and 5-year DFS according to the T stage (early and locally advanced). Short-term postoperative recovery outcomes included the mean time until decannulation and the mean time required for oral feeding restoration, which is expressed as the mean time until nasogastric tube (NGT) or percutaneous endoscopic gastrostomy (PEG) removal. According to $\mathrm{T}$ stage, patients were divided into two groups for statistical analysis, i.e., early (rT1-T2) and locally advanced (rT3-T4) groups.

\section{Data extraction}

Initial selection was performed via the screening of the titles and abstracts by two pairs of independent reviewers (GR and CAL, PC and DT). For detailed evaluations, fulltext copies of all studies except one (Shenoy et al., 2000) that were possibly relevant were obtained. The data from each study were extracted independently by paired and independent reviewers (GR and CAL, PC and DT) using a pre-standardised data abstraction form. The data extracted from the publications were independently checked for accuracy by two additional reviewers (PC and PD). We resolved any possible disagreements by consensus in consultation with a third reviewer (CAL) when needed.

\section{Quantitative analysis}

The meta-analysis was performed with a mixed random effect model using the DerSimonian and Laird method. The results were graphically represented using Forest plots. The proportions and 95\% CIs for each outcome were separately calculated for each trial with the grouped data using the intention-to-treat principle. The choice to use the proportions was driven by the design of meta-analysis, which was based on the included studies. The $\operatorname{tau}^{2}$ was used to define the between-studies variance. The $P$ value was set at 0.05 . The homogeneity assumption was examined with the $\mathrm{Q}$ test with a degree of freedom (df) equal to the number of analysed studies minus 1 . The heterogeneity was measured with the $\mathrm{I}^{2}$ statistic, which describes the percentage of total variation across studies that is due to heterogeneity rather than chance. The $\mathrm{I}^{2}$ was calculated from the basic results obtained from a typical meta-analysis as $\mathrm{I}^{2}=100 \% \AA \sim(\mathrm{Q}-\mathrm{df}) / \mathrm{Q}$, where $\mathrm{Q}$ is Cochran's heterogeneity statistic, and df is the degrees of freedom. A value of $0 \%$ indicates no observed heteroge- 
neity, and larger values indicate increasing heterogeneity. We performed an "a priori" sub-analysis of the oncological outcomes according to the early (rT1-T2) and locally advanced (rT3-T4) stages of recurrent laryngeal SCC. Next, we performed an "a priori" comparison of the same oncological outcomes between early (rT1-T2) and locally advanced (rT3-T4) stages of recurrent laryngeal SCC. For comparisons, we performed the meta-analyses with the odds ratios $(\mathrm{ORs})$, and 2 -sided $\mathrm{p}$-values $<0.05$ were considered significant.

The analyses were conducted with OpenMetaAnalyst (version 6) and SPSS version 20 (IBM SPSS).

To evaluate potential publication bias, we used a weighted linear regression and a modified Macaskill's test, which provides more balanced type I error rates in the tail probability areas relative to other publication bias tests ${ }^{15}$. GR conducted the statistical analyses.

\section{Limitations}

This systematic review and meta-analysis has some limitations that need to be addressed. We included only full papers in the English language and excluded abstracts. Moreover, all of the included studies were retrospective. We observed substantial heterogeneity $\left(\mathrm{I}^{2}>50 \%\right)$ according to the Cochrane guidelines in 4 of 10 outcomes considered.

\section{Results}

\section{Study selection}

We identified 276 references. One hundred eight-seven papers were excluded after reading the titles, and 70 were excluded after reading the abstracts. We analysed 19 retrospective studies in full paper format because no prospective or randomised studies were found. Fourteen references including 291 patients fulfilled our search criteria 7913 16-18 20-25 2728 . Six of these studies involved mixed series 7916172223 because they included patients who underwent primary SCL and salvage SCL after RT failure. The remaining eight papers focused only on salvage surgeries. Five references were excluded, including 3 mixed series whose authors ${ }^{12} 1929$ reported only the cumulative data for the series, one paper ${ }^{30}$ that was not available and one ${ }^{26}$ study that included other surgical techniques. Figure 1 illustrates the study selection process.

\section{Characteristics of studies included}

The 14 papers included 291 adult patients. The 5-year OS and 5-year DFS were reported in all papers with the exceptions of Farrag et al. ${ }^{22}$, Pellini et al. ${ }^{23}$ and de Vincentiis ${ }^{7}$. For the papers of Sperry et al. ${ }^{16}$, Nakayama et al. ${ }^{17}$, Deganello et al. ${ }^{20}$, Leon et al. ${ }^{21}$ and Marchese-Ragona et al. ${ }^{27}$, it was possible to extract these data from the text. All papers with the exceptions of Leone et al. ${ }^{9}$ and Nakayama et al. ${ }^{17}$ reported the short-term post-operative recovery

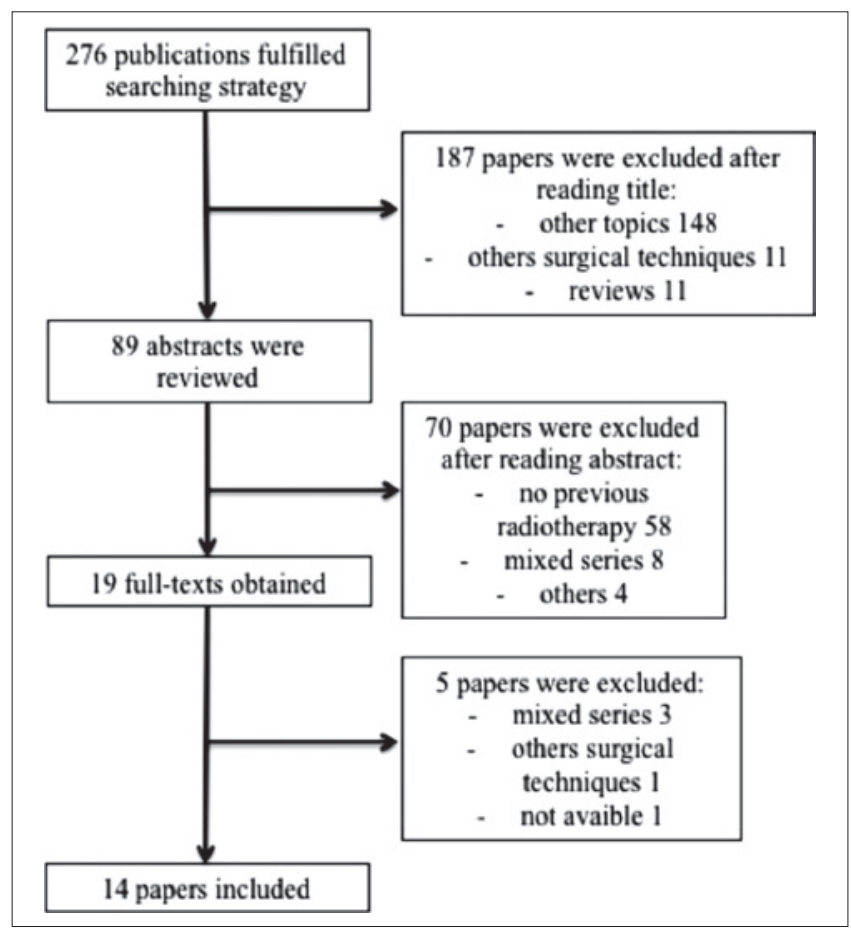

Fig. 1. We identified 276 references. One hundred eight-seven papers were excluded after reading the title, and 70 were excluded after reading the abstracts. We analysed 19 retrospective studies in full paper format. Fourteen references including 291 patients fulfilled our search criteria. Five references were excluded, including 3 mixed series whose authors reported only the cumulative data of the series, one paper that was not available and one that included other surgical techniques.

outcomes, and Sperry et al. ${ }^{16}$ and Pellini et al. ${ }^{23}$ reported only the cumulative data for their series. The main characteristics of the studies included are reported in Table I.

\section{Definitions of oncological and functional outcomes}

The oncological outcomes were calculated from the date of surgery. The endpoint for OS was the date of death regardless of cause, whereas the endpoint for DFS was date of recurrence (local, locoregional or metastatic). For the evaluations of short-term postoperative recovery, the outcomes included the mean time until decannulation and the mean time until NGT or PEG removal.

\section{Primary outcome}

The 5-year OS was 80.2\% (CI 0.719-0.885; $\mathrm{I}^{2}=62 \%$; $\mathrm{p}=0.003$ ), and the corresponding Forest plot is shown in Figure 2.

Figure 3 (upper box) shows the Forest plot for 5-year OS for T1-T2 (early stage according to TNM classification ${ }^{31}$ ) patients (proportion: 0.798; CI 0.686-0.911; $\mathrm{I}^{2}=35 \%$; $\mathrm{p}=0.167)$. The middle box shows the Forest plot for 5-year OS of T3-T4 patients (locally advanced stage; proportion: 0.923; CI 0.806-1.041; $\left.\mathrm{I}^{2}=0 \% ; \mathrm{p}=0.697\right)$. The lower box depicts the Forest plot for 5-year OS for early 
Table I. Main characteristics of the included studies (R: retrospective, NA: not available, RT: radiotherapy, CHP: cricohyoidopexy, CHEP: cricohyoidoepiglottopexy, +A: arytenoidectomy, NGT: nasogastric tube, PEG: percutaneous endoscopic gastrostomy).

\begin{tabular}{|c|c|c|c|c|c|c|c|c|c|c|c|c|}
\hline Author, Year & $\begin{array}{l}\text { Study } \\
\text { Type }\end{array}$ & Surrtgery & $\begin{array}{l}\text { Patients } \\
\text { (n) }\end{array}$ & $\begin{array}{l}\text { Age } \\
\text { (mean, } \\
\text { range) } \\
\text { in years }\end{array}$ & $\begin{array}{l}\text { Sex } \\
\text { (male, } \\
\text { female) }\end{array}$ & $\begin{array}{l}\text { Clinical } \\
\text { Stage } \\
\text { after RT }\end{array}$ & $\begin{array}{l}\text { Type of } \\
\text { Surgery }\end{array}$ & $\begin{array}{l}\text { Follow-Up } \\
\text { Period } \\
\text { (mean, } \\
\text { range) } \\
\text { in months }\end{array}$ & $\begin{array}{l}\text { 5-year } \\
\text { Overall } \\
\text { Survival }\end{array}$ & $\begin{array}{l}\text { 5-year } \\
\text { Disease } \\
\text { Free } \\
\text { Survival }\end{array}$ & $\begin{array}{l}\text { Decannulation } \\
\text { in days }\end{array}$ & $\begin{array}{l}\text { NGT } \\
\text { or PEG } \\
\text { removal } \\
\text { in days }\end{array}$ \\
\hline $\begin{array}{l}\text { De Vincentiis, } \\
2015\end{array}$ & $\mathrm{R}$ & $\begin{array}{l}\mathrm{RT} \text { and } \\
\text { laser failure }\end{array}$ & 20 & NA & NA & NA & NA & NA & NA & NA & $38,28-80$ & $25,20-39$ \\
\hline Leone, 2014 & $\mathrm{R}$ & $\begin{array}{l}\text { primary and } \\
\text { RT failure }\end{array}$ & 4 & $60,57-65$ & 4 male & $\begin{array}{l}\text { rT1b (1), } \\
\text { rT2 (3) }\end{array}$ & $\begin{array}{l}\text { CHP (3), } \\
\text { CHEP (1) }\end{array}$ & $41,12-60$ & $50 \%$ & $50 \%$ & NA & NA \\
\hline Sperry, 2013 & $\mathrm{R}$ & $\begin{array}{l}\text { primary and } \\
\text { RT failure }\end{array}$ & 42 & $60,34-79$ & $\begin{array}{l}37 \text { male, } \\
5 \text { female }\end{array}$ & $\begin{array}{l}\text { rT1a (10), } \\
\text { rT1b (13), } \\
\text { rT2 (12), } \\
\text { rT3 (61), } \\
\text { rT4 (1) }\end{array}$ & $\begin{array}{l}\text { CHP or } \\
\text { CHEP }\end{array}$ & $73,0-207$ & $95 \%$ & $90.5 \%$ & NA & NA \\
\hline $\begin{array}{l}\text { Nakayama, } \\
2013\end{array}$ & $\mathrm{R}$ & $\begin{array}{l}\text { primary and } \\
\text { RT failure }\end{array}$ & 30 & 62 & $\begin{array}{l}29 \text { male, } \\
1 \text { female }\end{array}$ & $\begin{array}{l}\text { rpT1 (5), } \\
\text { rpT2 (13), } \\
\text { rpT3 (9), } \\
\text { rpT4 (3) }\end{array}$ & CHEP (30) & NA & $81 \%$ & $96.6 \%$ & NA & NA \\
\hline $\begin{array}{l}\text { Luna-Ortiz, } \\
2009\end{array}$ & $\mathrm{R}$ & RT failure & 8 & $67,43-87$ & $\begin{array}{l}6 \text { male, } \\
2 \text { female }\end{array}$ & $\begin{array}{l}\text { rT1 (4), } \\
\text { rT2 (4) }\end{array}$ & $\begin{array}{l}\text { CHEP + A } \\
\text { (3), CHEP } \\
\text { (5) }\end{array}$ & $44,20-67$ & $50 \%$ & $50 \%$ & $16,3-56$ & $16,3-60$ \\
\hline $\begin{array}{l}\text { Deganello, } \\
2008\end{array}$ & $\mathrm{R}$ & RT failure & 31 & $\begin{array}{l}60.1,40- \\
72\end{array}$ & $\begin{array}{l}29 \text { male, } \\
2 \text { female }\end{array}$ & $\begin{array}{l}\text { rT1a (1), } \\
\text { rT1b (5), } \\
\text { rT2 (16), } \\
\text { rT3 (4), } \\
\text { rT3 (5) }\end{array}$ & $\begin{array}{l}\text { CHEP 8, } \\
\text { CHP } 23\end{array}$ & $45,6-180$ & $60 \%$ & $71 \%$ & $27,14-59$ & $30,12-72$ \\
\hline Pellini, 2008 & $\mathrm{R}$ & RT failure & 78 & $\begin{array}{l}59.6,33- \\
76\end{array}$ & 78 male & $\begin{array}{l}\text { rT1a (6), } \\
\text { rT1b (30), } \\
\text { rT2 (33), } \\
8 \text { rT3, 1 } \\
\text { rT4a }\end{array}$ & $\begin{array}{l}\text { CHEP + A } \\
\text { (33), CHEP } \\
(29), \text { CHP } \\
+ \text { A (8), } \\
\text { CHP (8) }\end{array}$ & $\begin{array}{l}70,10- \\
300\end{array}$ & $81.8 \%$ & $95.5 \%$ & $176.5,12-365$ & $15,12-90$ \\
\hline Leon, 2007 & $\mathrm{R}$ & RT failure & 9 & $\begin{array}{l}54.4,43- \\
67\end{array}$ & 9 male & $\begin{array}{l}\text { rT1a (5), } \\
\text { rT1b (2), } \\
\text { rT2 (1), } \\
\text { rT2 (1) }\end{array}$ & $\begin{array}{l}\text { CHEP (5), } \\
\text { CHEP + A } \\
\text { (1), CHP } \\
\text { (3) }\end{array}$ & $\begin{array}{l}\text { mean NA, } \\
4-120\end{array}$ & $78 \%$ & $89 \%$ & $11,6-60$ & $27,16-40$ \\
\hline Farrag, 2007 & $\mathrm{R}$ & $\begin{array}{l}\text { primary and } \\
\text { RT failure }\end{array}$ & 10 & NA & NA & $\begin{array}{l}\text { rT1 (1), } \\
\text { rT2 (7), } \\
\text { rT3 (2) }\end{array}$ & NA & NA & NA & NA & $52,19-123$ & $\begin{array}{l}90,30- \\
210\end{array}$ \\
\hline Pellini, 2006 & $\mathrm{R}$ & $\begin{array}{l}\text { primary and } \\
\text { RT failure }\end{array}$ & 17 & NA & NA & $\begin{array}{l}\text { rT1a (4), } \\
\text { rT1b (3), } \\
\text { rT2 (8), } \\
\text { rT2 (1), } \\
\text { rT3 (1) }\end{array}$ & $\mathrm{CHP}$ & NA & NA & NA & $21.7,6-65$ & NA \\
\hline $\begin{array}{l}\text { Sewnaik, } \\
2006\end{array}$ & $\mathrm{R}$ & RT failure & 14 & $\begin{array}{l}\text { mean NA, } \\
49-79\end{array}$ & $\begin{array}{l}12 \text { male, } \\
2 \text { female }\end{array}$ & $\begin{array}{l}\text { rTis (1), T1 } \\
(6), \text { T2 (7) }\end{array}$ & CHEP 14 & $16,3-41$ & $92.8 \%$ & $85.7 \%$ & $176.5,12-365$ & $\begin{array}{l}45,10- \\
120\end{array}$ \\
\hline Clark, 2005 & $\mathrm{R}$ & RT failure & 6 & $\begin{array}{l}\text { mean NA, } \\
51-64\end{array}$ & NA & $\begin{array}{l}\text { rT1a (2), } \\
\text { rT1b (1), } \\
\text { rT2 (3) }\end{array}$ & $\begin{array}{l}\text { CHEP (4), } \\
\text { CHP (2) }\end{array}$ & $\begin{array}{l}19 \text {, range } \\
\text { NA }\end{array}$ & $72 \%$ & $100 \%$ & $9,6-13$ & $\begin{array}{l}165,60- \\
300\end{array}$ \\
\hline $\begin{array}{l}\text { Marchese, } \\
2005\end{array}$ & $\mathrm{R}$ & $\mathrm{RT}$ failure & 7 & $64,55-72$ & 7 male & $\begin{array}{l}\text { rT2 (6), } \\
\text { rT3 (1) }\end{array}$ & $\mathrm{CHP}(7)$ & $\begin{array}{l}122,72- \\
173\end{array}$ & $86 \%$ & $86 \%$ & NA & $\begin{array}{l}42,20- \\
130\end{array}$ \\
\hline $\begin{array}{l}\text { Spriano, } \\
2002\end{array}$ & $\mathrm{R}$ & RT failure & 15 & $\begin{array}{l}65.2,58- \\
63\end{array}$ & 15 male & $\begin{array}{l}\text { rT1a (4), } \\
\text { rT1b (3), } \\
\text { rT2 (6), } \\
\text { rT2 (1) }\end{array}$ & $\begin{array}{l}\text { CHEP (7), } \\
\text { CHEP + A } \\
\text { (4), CHP } \\
\text { (3), CHP + } \\
\text { A (1) }\end{array}$ & $\begin{array}{l}63.5,36- \\
104\end{array}$ & $80 \%$ & $93.3 \%$ & $21.7,6-65$ & $\begin{array}{l}23.2,12- \\
48\end{array}$ \\
\hline
\end{tabular}




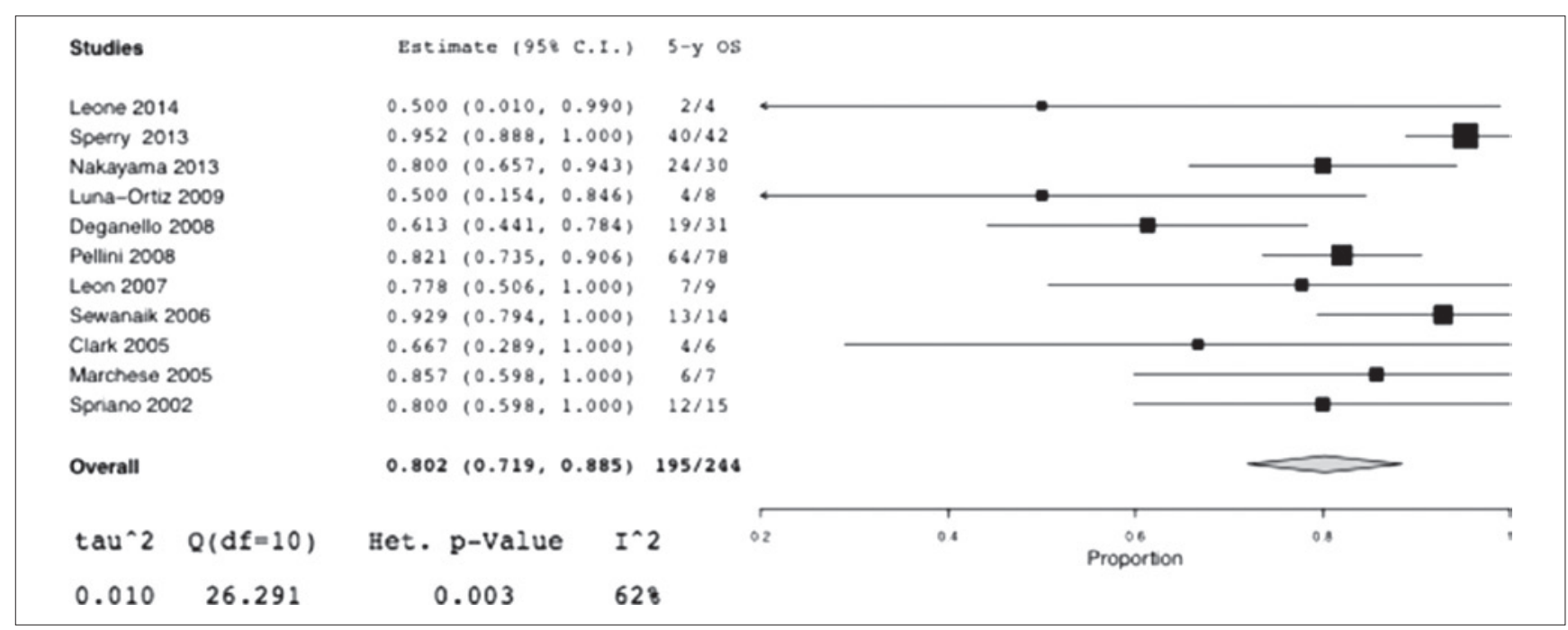

Fig. 2. Forrest plot of 5-year OS for patients treated with supracricoid laryngectomy after radiation therapy failure. Weights: Leone 2014: 2.5\%, Sperry 2013 16.9\%, Nakayama 2013: 12\%, Luna-Ortiz 2009: 4.4\%, Deganello 2008: 10.4\%, Pellini 2008: 15.7\%, Leon 2007: 6.2\%, Sewanaik 2006: 12.5\%, Clark 2005: 3.8\%, Marchese 2005: 6.6\%, Spriano 2002: 8.9\%.

vs locally advanced SCC patients (OR: 0.670; CI 0.117$\left.3.855 ; \mathrm{I}^{2}=7 \% ; \mathrm{p}=0.340\right)$.

\section{Secondary outcomes}

The 5-year DFS was $89.5 \%$ (CI $0.838-0.952 ; \mathrm{I}^{2}=52 \%$; $\mathrm{p}=0.022$ ) as illustrated in Figure 4. Figure 5 (upper box) displays the Forest plot for the 5-year DFS of the T1-T2 patients (early stage; proportion: 0.869; CI 0.792-0.946; $\left.\mathrm{I}^{2}=15 \% ; \mathrm{p}=0.315\right)$. The middle box presents the Forest plot for the 5-year DFS of the T3-T4 patients (locally advanced stage; proportion: 0.911 ; CI $0.784-1.037 ; \mathrm{I}^{2}=0 \%$; $\mathrm{p}=0.812$ ). The lower box shows the Forest plot for the 5 -year DFS of early vs. locally advanced stage patients (OR: 0.475; CI 0.093-2.430; $\mathrm{I}^{2}=0 \% ; \mathrm{p}=0.841$ ).

The mean time until decannulation was 35.6 days (CI $\left.24.3-46.9 ; \mathrm{I}^{2}=95 \% ; \mathrm{p}<0.001\right)$, and the corresponding Forest plot is presented in Figure 6. The mean time until NGT or PEG removal was 28.3 days (CI 22.7-33.8; $\mathrm{I}^{2}=86 \% ; \mathrm{p}<=0.001 ;$ Fig. 7 ).

\section{Publication bias}

No publication bias was detected according to Macaskill's modified test.

\section{Discussion}

In most centres in northern Europe and North America, radiotherapy is the primary treatment for patients with early laryngeal SCC ${ }^{32}$. RT is a well-established treatment for selected laryngeal carcinomas that elicits good oncologic and functional results. The reported failure rates range between $9-21 \%$ for $\mathrm{T} 1$ and $28-37 \%$ for $\mathrm{T} 2$ glottic carcinomas. In supraglottic laryngeal cancer, the reported failure rates for $\mathrm{T} 1$ and $\mathrm{T} 2$ lesions are $24-30 \%$ and $25 \%$ -
$45 \%$, respectively ${ }^{33}$. Re-irradiation protocols (in combination with radio-sensitising agents) are at significant risk for morbidity ${ }^{34}{ }^{35}$ and remain investigational; they may be considered for patients with unresectable locoregional disease. Therefore, surgery is the preferred modality for curative treatment of recurrent laryngeal cancer after failure of nonsurgical treatments. There are three options for salvage surgery after radiation failure: total laryngectomy, transoral laser microsurgery (TLM) and open partial laryngectomy.

Total laryngectomy is widely considered the classic approach to glottic SCC recurrence after irradiation ${ }^{36}$, but considerably impairs the quality of life primarily due to the permanent tracheostoma and the loss of voice ${ }^{9}$. Compared with alternative treatment options for laryngeal cancer, the oncological outcomes of TLM are inferior to those of open partial laryngectomy. TLM has a relatively lower mean larynx preservation rate of $72.3 \%$ versus $84 \%$ for open partial laryngectomy, which reflects a higher locoregional failure rate after TLM ${ }^{8}$. In the radio-recurrent setting, open partial laryngectomies have been less commonly used in the past due to concerns about unpredictable spreading and the postoperative function of the irradiated organ as well as a higher risk of complications ${ }^{8}$. The correct assessment of tumour extension of a recurrent laryngeal carcinoma may be difficult due to the residual inflammatory or functional changes associated with radiation therapy. Many recurrences present with multicentric tumour foci that are localised below intact mucosa and further masked by post-treatment oedema and fibrosis ${ }^{37}$. This pathological phenomenon that results in clinically significant difficulties in correctly restaging the tumour after irradiation justify the classical choice of salvage total laryngectomy in cases of carcinoma recurrence fol- 


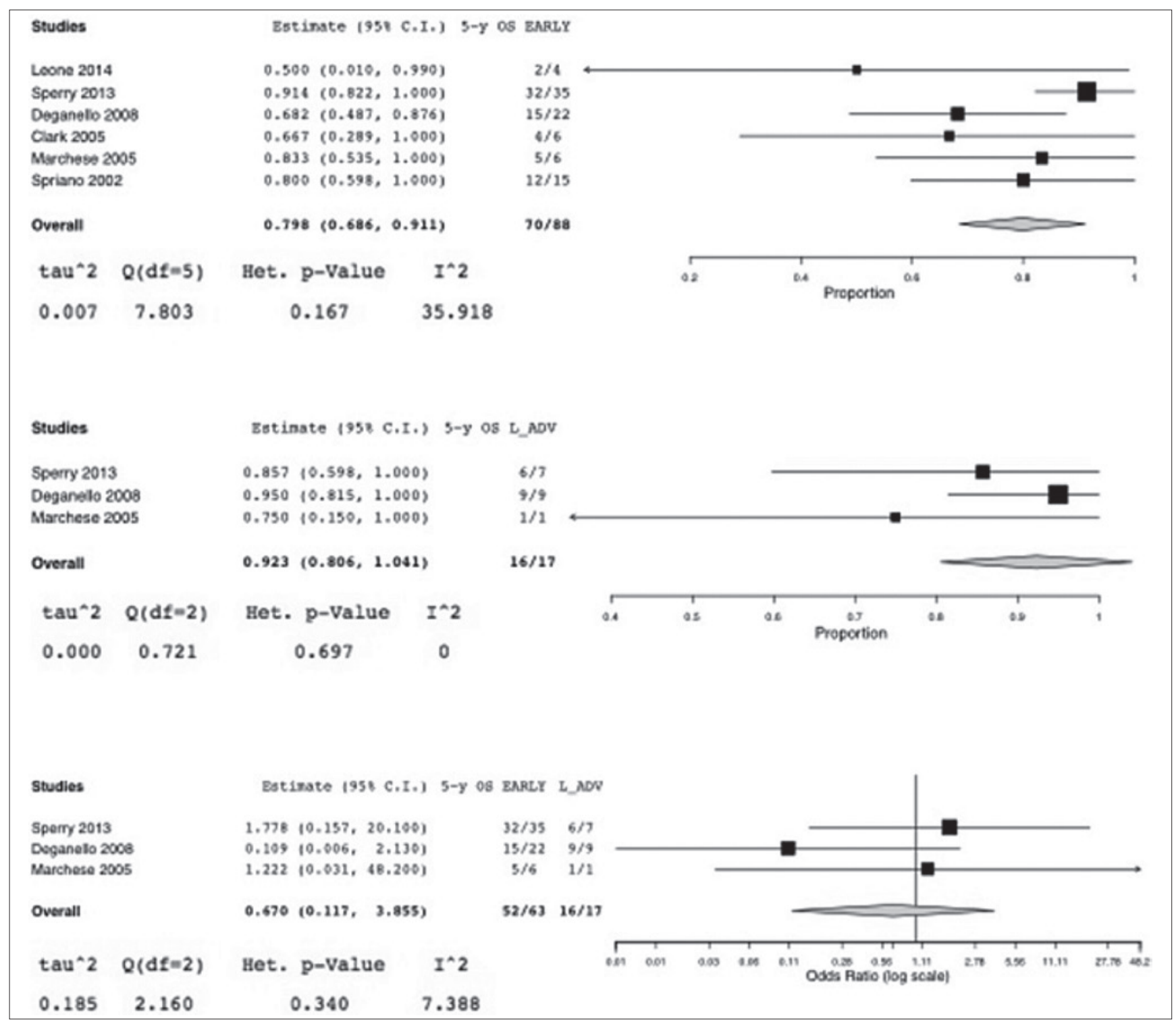

Fig. 3. Upper box: Forest plot of 5-year OS for patients affected with "early" T1-T2 recurrent laryngeal cancer after radiation therapy failure who were treated with supracricoid laryngectomy. Weights: Leone 2014: 4.8\%, Sperry 2013 37.3\%, Deganello 2008: 20.1\%, Clark 2005: 7.6\%, Marchese 2005: 11.1\%, Spriano 2002: 19.1\%.Middle box: Forest plot of the 5-year OS for patients affected with "locally advanced" T3-T4 recurrent laryngeal cancer following radiation therapy RT failure who were treated with SCL. Weights: Sperry 2013 20.6\%, Deganello 2008: 75.6\%, Marchese 2005: 3.8\%. Lower box: Forest plot of the 5-year OS for patients affected with "early" vs. "locally advanced" recurrent laryngeal cancer following radiation therapy failure who were treated with supracricoid laryngectomy. Weights: Sperry 2013 43.4\%, Deganello 2008: 32\%, Marchese 2005: 21.6\%.

lowing radiotherapy failure ${ }^{29}$. There have been several reports about the effectiveness of open partial laryngectomies in terms of survival and functional results in residual or recurrent cancer.

To our knowledge, this is first systematic review and meta-analysis to examine the oncological outcomes according to $\mathrm{T}$ stage and short-term postoperative recovery outcomes of SCL for treatment of laryngeal SCC after RT failure.

This systematic review and meta-analysis resulted in the following findings: 1) 5-year OS was $80.2 \%$; 2) 5-year DFS was $89.5 \%$; 3) mean time until decannulation was 35.6 days; and 4) mean time until NGT or PEG removal was 28.3 days. The studies included in this meta-analysis share a common trait, i.e., the strict criteria for patient selection for candidacy for SCL after RT failure ${ }^{9}$. The indications and contraindications after the failure of RT are similar to those that have been specified for patients with previously untreated laryngeal tumours ${ }^{30}$. Therefore, we hypothesise that careful assessment of tumour extension might be responsible for the high 5-year OS and 5-year DFS. 


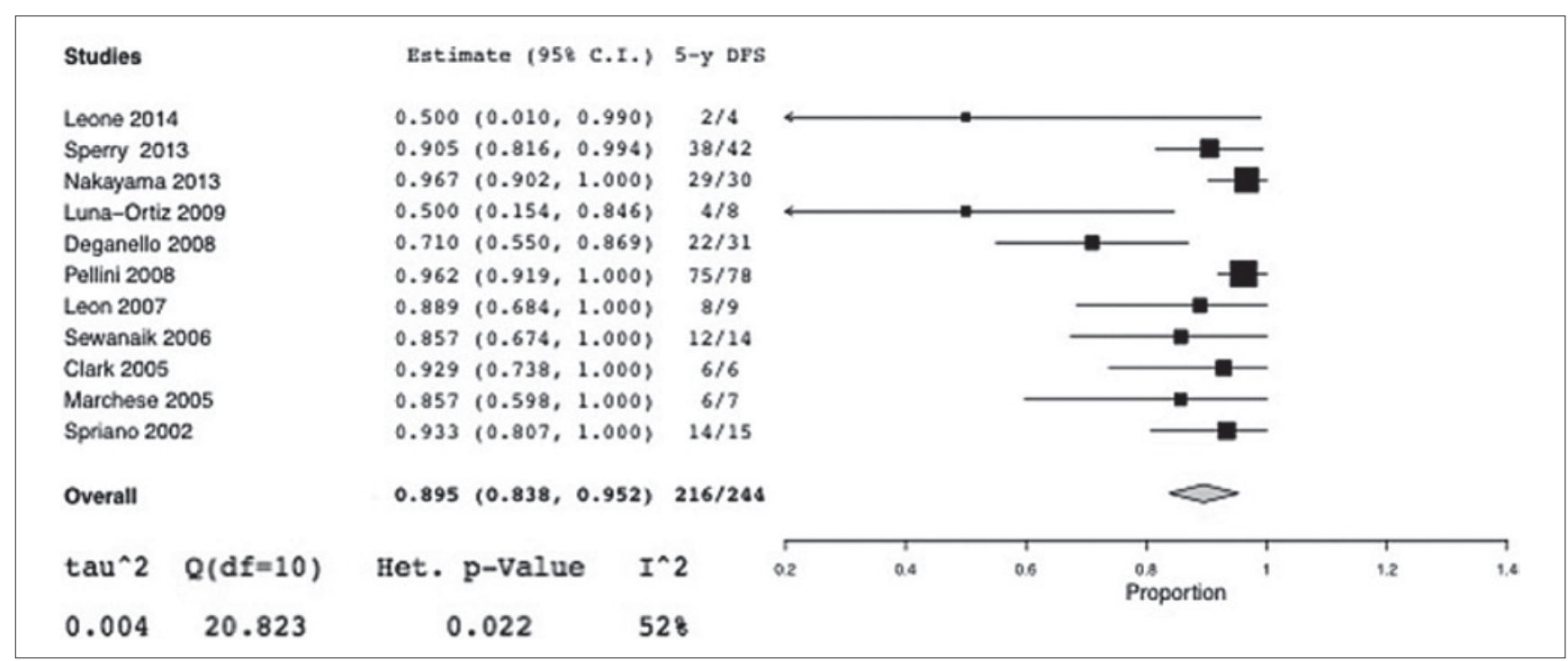

Fig. 4. Forest plot of the 5-year DFS for patients who were treated with supracricoid laryngectomy after radiation therapy failure. Weights: Leone 2014: 1.3\%, Sperry 2013 15\%, Nakayama 2013: 18.2\%, Luna-Ortiz 2009: 2.4\%, Deganello 2008: 8.3\%, Pellini 2008: 20.8\%, Leon 2007: 5.8\%, Sewanaik 2006: 6.8\%, Clark 2005: 6.5\%, Marchese 2005: 4\%, Spriano 2002: $10.9 \%$.

In our sub-analysis, we found that 5-year OS for T1-T2 patients (early stage) was $79.8 \%$; interestingly, this rate was $92.3 \%$ for T3-T4 patients (locally advanced stage). The 5-year DFS was $86.9 \%$ for T1-T2 patients and $91.1 \%$ for T3-T4 patients. These data might be attributable to inaccurate staging (i.e., understaging) prior to salvage surgery. In this regard, Zbaren et al. ${ }^{37}$ reported that $52 \%$ of patients were clinically understaged and that the diagnostic accuracy of clinical evaluation (via fiberoptic laryngoscopy, CT, MRI, or microlaryngoscopic examination findings) was only $38 \%$.

Nevertheless, our statistical analysis demonstrated that the differences between the 5-year OS and DFS of early and locally advanced SCC patients were not significantly different ( $\mathrm{p}=0.340$ and $\mathrm{p}=0.841$, respectively). However, these results may have been influenced by the small size of the locally advanced stage group (only 17 patients).

Some of the papers included in this meta-analysis ${ }^{91623-25} 27$ reported only clinical TNM. We strongly believe that future studies should also report pathological stage after salvage surgery.

The theoretical advantage of SCL over TL is that at least one functioning crico-arytenoid joint is maintained, and thus a permanent tracheostoma is not required, and the main laryngeal functions (i.e., respiration, phonation and swallowing) are preserved. Nevertheless, swallowing impairment represents the main functional issue due to the modification of the hypopharyngo/laryngeal anatomy. This condition has implications for the quality of life in addition to an association with potentially life threatening complications, such as aspiration pneumonia ${ }^{38} 39$.

This meta-analysis demonstrated that the mean time until NGT or PEG removal was 28.3 days, and the mean time until decannulation was 35.6 days. These data accord with the reports of other authors ${ }^{40} 41$ who prefer the initial removal of the NGT and initiation of oral alimentation with a tracheostomy tube to protect and clean the airways and permit the suction of any residual food that may be present ${ }^{13}$. However, the proper postoperative management of tracheostomies is still under debate. In contrast, different authors ${ }^{28} 29$ 42-56 have proposed early removal of the tracheostomy tube to ensure a rapid mobilisation of the residual larynx to avoid any interference with the cough reflex, which limits the incidence of pulmonary infection ${ }^{13}$. These different approaches might be due to personal experience or the preferences of the surgeon.

Some authors ${ }^{2736}$ have suggested that, in consideration of the possibility of long-lasting swallowing disorders, clinicians should consider preoperative PEG in patients undergoing SCL as a salvage surgery for glottic carcinoma after irradiation failure. This suggestion is consistent with the opinion of the majority of the authors of the studies included in the present meta-analysis 13161822252728 . SCLs allow for satisfactory functional results, but surgical protocols need to be followed by adequate nursing and rehabilitation protocols. However, there is no evidence regarding when rehabilitation should be initiated, which criteria should be adopted to indicate the initiation and termination of rehabilitation, or which voice and swallowing rehabilitation procedures provide the optimal functional outcomes ${ }^{57}$. Therefore, we recommend that future work should focus on standardising postoperative care and rehabilitation protocols. 


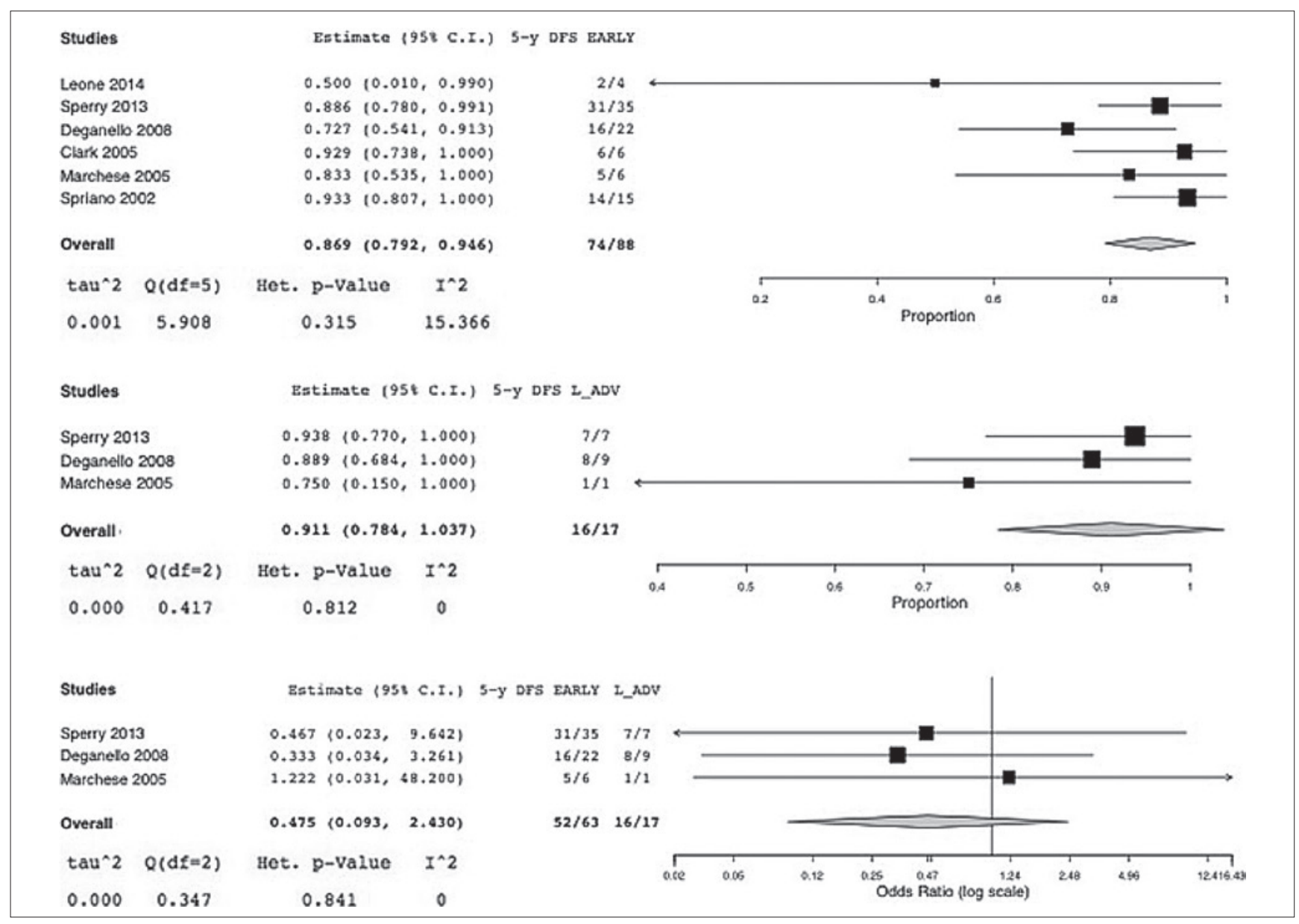

Fig. 5. Upper box: Forest plot of the 5-year DFS for patients affected with "early" T1-T2 recurrent laryngeal cancer after radiation therapy failure who were treated with supracricoid laryngectomy. Weights: Leone 2014: 2.4\%, Sperry 2013 35.3\%, Deganello 2008: 14.6\%, Clark 2005: 14\%, Marchese 2005: 6.2\%, Spriano 2002: 27.4\%. Middle box: Forest plot of the 5-year DFS for patients affected with "locally advanced" T3-T4 recurrent laryngeal cancer after radiation therapy failure who were treated with supracricoid laryngectomy. Weights: Sperry 2013 57.3\%, Deganello 2008: 38.2\%, Marchese 2005: 4.5\%. Lower box: Forest plot of the 5-year DFS for patients affected with "early" vs. "locally advanced" recurrent laryngeal cancer following after radiation therapy failure who were treated with supracricoid laryngectomy. Weights: Sperry 2013 29\%, Deganello 2008: 51.3\%, Marchese 2005: 19.7\%.

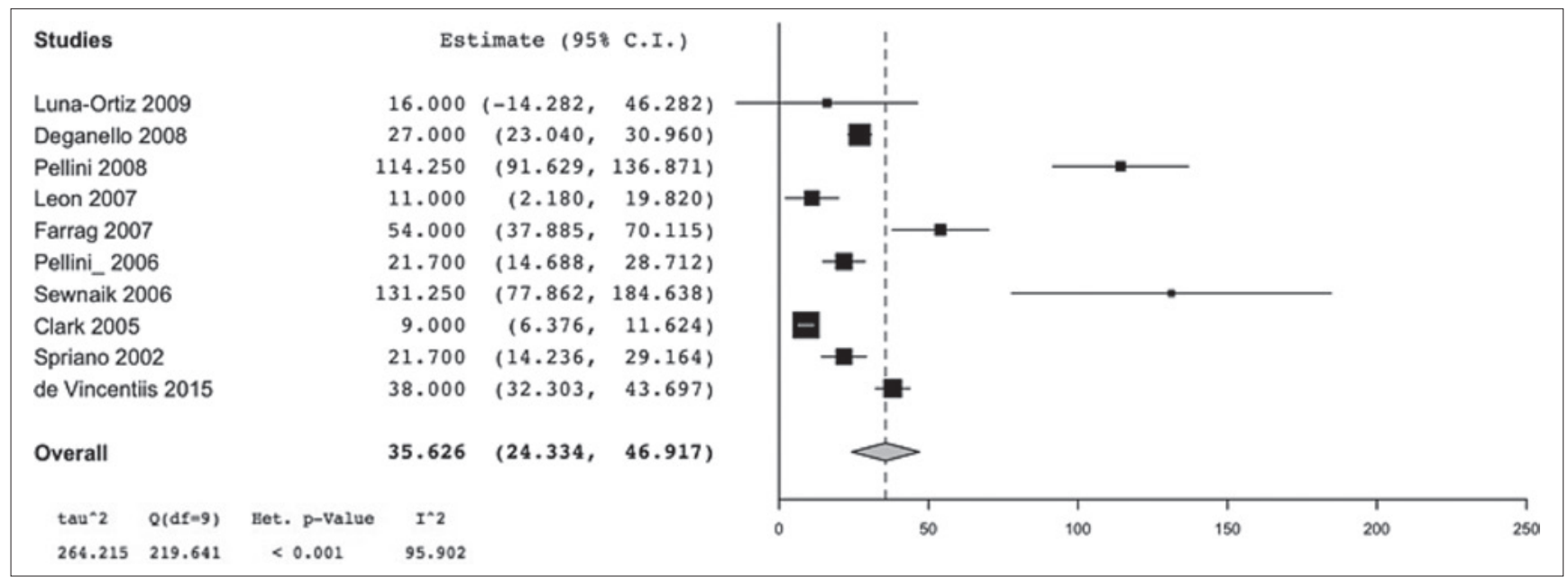

Fig. 6. Forest plot of the mean time until decannulation (days) for patients who were treated with supracricoid laryngectomy after radiation therapy failure. Weights: Luna-Ortiz 2009: 6.5\%, Deganello 2008: 12.2\%, Pellini 2008: 8.2\%, Leon 2007: 11.5\%, Farrag 2007: 9.9\%, Pellini 2006: 11.8\%, Sewanaik 2006: 3.2\%, Clark 2005: 12.3\%, Spriano 2002: 11.8\%, de Vincentiis 2015: $12 \%$. 


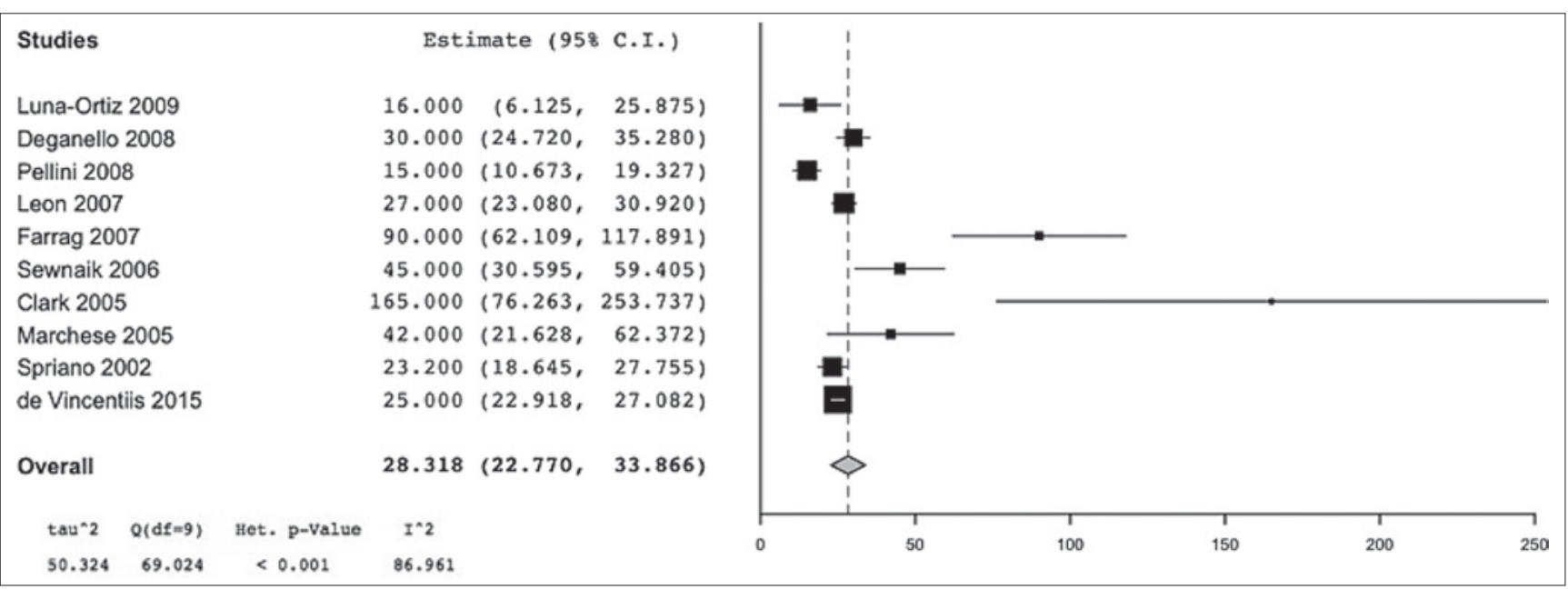

Fig. 7. Forest plot of the mean time until NGT or PEG removal (days) for patients who were treated with supracricoid laryngectomy after radiation therapy failure. Weights: Luna-Ortiz 2009: 10.5\%, Deganello 2008: 13.9\%, Pellini 2008: 14.5\%, Leon 2007: 14.7\%, Farrag 2007: 3.1\%, Sewanaik 2006: 7.6\%, Clark 2005: 0.3\%, Marchese 2005: 5\%, Spriano 2002: 14.3\%, de Vincentiis 2015: 15.5\%.

\section{Conclusions}

Recurrent laryngeal cancer after irradiation is a difficult clinical problem. Although total laryngectomy has been widely considered for many years to be the treatment of choice, this meta-analysis demonstrated that supracricoid laryngectomy for recurrent laryngeal cancer after chemoradiotherapy provides reliable oncological and short-term postoperative recovery outcomes.

\section{References}

1 Mendenhall WM, Parsons JT, Stringer SP, et al. T1-T2 vocal cord carcinoma: a basis for comparing the results of radiotherapy and surgery. Head Neck Surg 1988;10:373-7.

2 Woodhouse RJ, Quivey JM, Fu KK, et al. Treatment of carcinoma of the vocal cord. A review of 20 years experience. Laryngoscope 1981;92:1155-62.

3 Viani L, Stell PM, Dalby JE. Recurrence after radiotherapy for glottic carcinoma. Cancer 1991;67:577-84.

4 Schwaab G, Mamelle G, Lartigau E, et al. Surgical salvage treatment of T1/T2 glottic carcinoma after failure of radiotherapy. Am J Surg 1994;168:474-6.

5 Rizzotto G, Crosetti E, Lucioni M, et al. Subtotal laryngectomy: outcomes of 469 patients and proposal of a comprehensive and simplified classification of surgical procedures. Eur Arch Otorhinolaryngol 2012;269:1635-46.

6 Laudadio P, Presutti L, Dall'olio D, et al. Supracricoid laryngectomies: long-term oncological and functional results. Acta Otolaryngol 2006;126:640-9.

7 de Vincentiis M, De Virgilio A, Bussu F, et al. Oncologic results of the surgical salvage of recurrent laryngeal squamous cell carcinoma in a multicentric retrospective series: emerging role of supracricoid partial laryngectomy. Head Neck 2015;37:84-91

8 Paleri V, Thomas L, Basavaiah N, et al. Oncologic out- comes of open conservation laryngectomy for radiorecurrent laryngeal carcinoma: a systematic review and meta-analysis of English-language literature. Cancer 2011;117:2668-76.

9 Leone CA, Capasso P, Russo G, et al. Supracricoid laryngectomies: oncological and functional results for 152 patients. Acta Otorhinolaryngol Ital 2014;34:317-26.

10 Succo G, Peretti G, Piazza C, et al. Open partial horizontal laryngectomies: a proposal for classification by the working committee on nomenclature of the European Laryngological Society. Eur Arch Otorhinolaryngol 2014;271:2489-96.

11 Bron L, Brossard E, Monnier P, et al. Supracricoid partial laryngectomy with cricohyoidoepiglottopexy and cricohyoidopexy for glottic and supraglottic carcinomas. Laryngoscope 2000;110:627-34.

12 Cho KJ, Joo YH, Sun DI, et al. Supracricoid laryngectomy oncologic validity and functional safety. Eur Arch Otorhinolaryngol 2010;267:1919-25.

13 Pellini R, Pichi B, Ruscito P, et al. Supracricoid partial laryngectomies after radiation failure: a multi-institutional series. Head Neck 2008;30:372-9.

14 Pinar E, Imre A, Calli C, et al. Supracricoid partial laryngectomy: analyses of oncologic and functional outcomes. Otolaryngol Head Neck Surg 2012;147:1093-8.

15 Peters JL, Sutton AJ, Jones DR, et al. Comparison of two methods to detect publication bias in meta-analysis. JAMA 2006;295:676-80.

16 Sperry SM, Rassekh CH, Laccourreye O, et al. Supracricoid partial laryngectomy for primary and recurrent laryngeal cancer. JAMA Otolaryngol Head Neck Surg 2013;139:1226-35.

17 Nakayama M, Okamoto M, Hayakawa K, et al. Clinical outcome of supracricoid laryngectomy with cricohyoidoepiglottopexy: radiation failure versus previously untreated patients. Auris Nasus Larynx 2013;40:207-10. 
18 Luna-Ortiz K, Pasche P, Tamez-Velarde M, et al. Supracricoid partial laryngectomy with cricohyoidoepiglottopexy in patients with radiation therapy failure. World J Surg Oncol 2009; 7:101.

19 Soudry E, Marmor Y, Hazan A, et al. Supracricoid partial laryngectomy: an alternative to total laryngectomy for locally advanced laryngeal cancers. J Laryngol Otol 2008;122:1219-23.

20 Deganello A, Gallo O, De Cesare JM, et al. Supracricoid partial laryngectomy as salvage surgery for radiation therapy failure. Head Neck 2008;30:1064-71.

21 León X, López M, García J, et al. Supracricoid laryngectomy as salvage surgery after failure of radiation therapy. Eur Arch Otorhinolaryngol 2007;264:809-14.

${ }^{22}$ Farrag TY, Koch WM, Cummings CW, et al. Supracricoid laryngectomy outcomes: The Johns Hopkins experience. Laryngoscope 2007;117:129-32.

${ }^{23}$ Pellini R, Manciocco V, Spriano G. Functional outcome of supracricoid partial laryngectomy with cricohyoidopexy: radiation failure vs previously untreated cases. Arch Otolaryngol Head Neck Surg 2006;132:1221-5.

24 Sewnaik A, Hakkesteegt MM, Meeuwis CA, et al. Supracricoid partial laryngectomy with cricohyoidoepiglottopexy for recurrent laryngeal cancer. Ann Otol Rhinol Laryngol 2006;115:419-24.

25 Clark J, Morgan G, Veness M, et al. Salvage with supracricoid partial laryngectomy after radiation failure. ANZ J Surg 2005;75:958-62.

26 Makeieff M, Venegoni D, Mercante G, et al. Supracricoid partial laryngectomies after failure of radiation therapy. Laryngoscope 2005;115:353-7.

27 Marchese-Ragona R, Marioni G, Chiarello G, et al. Supracricoid laryngectomy with cricohyoidopexy for recurrence of early-stage glottic carcinoma after irradiation. Long-term oncological and functional results. Acta Otolaryngol 2005;125:91-5.

28 Spriano G, Pellini R, Romano G, et al. Supracricoid partial laryngectomy as salvage surgery after radiation failure. Head Neck 2002;24:759-65.

29 Laccourreye O, Weinstein G, Naudo P, et al. Supracricoid partial laryngectomy after failed laryngeal radiation therapy. Laryngoscope 1996;106:495-8.

30 Shenoy AM, Kumar SS, Nanjundappa, et al. Supracricoid laryngectomy with Cricohyoidopexy - a clinico oncological \& functional experience. Indian J Cancer 2000;37:67-73.

31 Union International Contre le Cancer. TNM classification of malignant tumors. $7^{\text {th }}$ edn. New York: Wiley-Liss 2010.

32 Jørgensen K, Godballe $\mathrm{C}$, Hansen $\mathrm{O}$, et al. Cancer of the larynx - treatment results after primary radiotherapy with salvage surgery in a series of 1005 patients. Acta Oncol 2002;41:69-76.

33 Yiotakis J, Stavroulaki P, Nikolopoulos T, et al. Partial laryngectomy after irradiation failure. Otolaryngol Head Neck Surg 2003;128:200-9.

34 Sher DJ, Haddad RI, Norris CM Jr, et al. Efficacy and toxicity of reirradiation using intensity-modulated radiotherapy for recurrent or second primary head and neck cancer. Cancer 2010;116:4761-8.
35 Spencer SA, Harris J, Wheeler RH, et al. Final report of RTOG 9610, a multi-institutional trial of reirradiation and chemotherapy for unresectable recurrent squamous cell carcinoma of the head and neck. Head Neck 2008;30:281-8.

36 Marioni G, Marchese-Ragona R, Pastore A, et al. The role of supracricoid laryngectomy for glottic carcinoma recurrence after radiotherapy failure: a critical review. Acta Otolaryngol 2006;126:1245-51.

37 Zbären P, Nuyens M, Curschmann J, et al. Histologic characteristics and tumor spread of recurrent glottic carcinoma: analysis on whole-organ sections and comparison with tumor spread of primary glottic carcinomas. Head Neck 2007;29:26-32.

38 Hutcheson KA, Lewin JS, Holsinger FC, et al. Long-term functional and survival outcomes after induction chemotherapy and risk-based definitive therapy for locally advanced squamous cell carcinoma of the head and neck. Head Neck 2014;36:474-80.

39 Hutcheson KA, Lewin JS, Barringer DA, et al. Late dysphagia after radiotherapy-based treatment of head and neck cancer. Cancer 2012;118:5793-9.

40 Guerrier B, Lallemant JG, Balmigere G, et al. Notre experience de la chirurgie reconstructive dans les cancers glottiques. Ann Otolaryngol Chir Cervicofac 1987;104:175-9.

${ }_{41}$ Traissac 1, Verhulst J. Indications techniques et resultats des laryngectomies reconstructives. Rev laryngol Otol Rhinol (Bord) 1991;112:55-8.

42 American Joint Committee on Cancer. Manual for staging of cancer, 6th ed. Philadelphia, PA: JB Lippincott 2002.

${ }^{43}$ Cox DR. Regression models and life-tables. J R Stat Soc Ser B 1972;34:187-202.

44 Toma M, Nibu K, Nakao K, et al. Partial laryngectomy to treat early glottic cancer after failure of radiation therapy. Arch Otolaryngol Head Neck Surg 2002;128:909-12.

45 Virtaniemi JA, Hirvikoski PP, Kumpulainen EJ, et al. Surgical management of irradiation failures in T1-T2 squamous cell carcinoma of the glottic larynx. Anticancer Res 2001;21:4185-8.

46 Spriano G, Piantanida R, Maffioli M. Salvage surgery after unsuccessful radiotherapy of cancer of the larynx. Acta Otorhinolaryngol Ital 1989;9:161-8.

47 Shah JP, Loree TR, Kowalski L. Conservation surgery for radiation-failure carcinoma of the glottic larynx. Head Neck 1990;12:321-6.

48 Sparano A, Chernock R, Feldman M, et al. Extending the inferior limits of supracricoid partial laryngectomy: a clinicopathological correlation. Laryngoscope 2005;115:297-300.

49 Dufour X, Hans S, De Mones E, et al. Local control after supracricoid partial laryngectomy for "advanced" endolaryngeal squamous cell carcinoma classified as T3. Arch Otolaryngol Head Neck Surg 2004;130:1092-9.

50 Kirchner JA. What have whole organ sections contributed to the treatment of laryngeal cancer? Ann Otol Rhinol Laryngol 1989;98:661-7.

51 Brasnu DF. Supracricoid partial laryngectomy with cricohyoidopexy in the management of laryngeal carcinoma. World J Surg 2003;27:817-23. 
52 Weinstein GS, El-Sawy MM, Ruiz C, et al. Laryngeal preservation with supracricoid partial laryngectomy results in improved quality of life when compared with total laryngectomy. Laryngoscope 2001;111:191-9.

53 Ware JE, Kosinski M, Keller SD. SF-36 Physical and mental health summary scale: a user manual. Boston: The Health Institute, New England Medical Center 1994.

54 Hogikyan ND, Girish S. Validation of an instrument to measure voice-related quality of life (V-RQOL). J Voice 1999:13:557-69.
55 Naudo P, Laccourreye O, Weinstein G, et al. Complications and functional outcome after supracricoid partial laryngectomy with cricohyoidoepiglottopexy. Otolaryngol Head Neck Surg 1998;118:124-9.

56 Kaplan EL, Meier P. Nonparametric estimation from incomplete observations. J Am Stat Assoc 1958;53:457-81.

57 Schindler A, Pizzorni N, Mozzanica F, et al. Functional outcomes after supracricoid laryngectomy: what do we not know and what do we need to know? Eur Arch Otorhinolaryngol 2015;273:3459-75.

Received: January 23, 2016 - Accepted: September 21, 2016

Address for correspondence: Carlo Antonio Leone, Otolaryngology Head and Neck Surgery Unit of "Azienda Ospedaliera di Rilievo Nazionale dei Colli, Ospedale Monaldi", Naples, Italy. Tel. +39 081 7062431. Fax +39081 7064270. E-mail: carloantonioleone@ hotmail.com 